\title{
THE ESTABLISHMENT AND OPERATION OF SÄMOA'S POLITICAL PARTY SYSTEM
}

Asofou So'o

\section{Abstract}

When Sämoa gained independence in 1962, it was expected to adopt the Westminster model of parliamentary democracy. Framers of Sämoa's Constitution had, therefore, always envisaged the formation of political parties in the nation, but it was 17 years after independence before this vision became a reality. The consensus politics that dominated the first two decades of independence were swiftly replaced by party politics after the establishment of the first post-independence political party. Immediately thereafter, more political parties were formed, giving rise to the party system Sämoa still has today, in which the party in government is able to pass laws for the development of the country that would have otherwise been impossible. The nature of Sämoan political parties their structures and the strategies they have adopted to keep their members tied to their collective cause and to win support during election campaigns - is partly a reflection of the political environment within which they operate. As the party system becomes entrenched, however, it has become increasingly associated with a widespread feeling of powerlessness and political paralysis among parliamentarians and the public generally. Nevertheless, as this chapter argues, the Sämoan political parties are here to stay, albeit with continuing piecemeal adjustments that are intended to consolidate the system.

\section{Introduction}

Sämoa gained independence on January 1, 1962, and its constitution ${ }^{1}$ provides for a parliamentary democracy of the Westminster model. Until the 1993 enactment of the 1991 constitutional amendment ${ }^{2}$ that extended the parliamentary term from three to 
five years, general elections were held every three years to select representatives to occupy the 49 seats of Parliament. There are 41 territorial constituencies, six of which have two seats each because of their larger voter population. Upolu Island has four of these seats and the larger island of Savai'i has the other two. Thus, of the 49 seats in Parliament, 47 are occupied by representatives of the 41 territorial constituencies who must hold matai (chiefly) titles. ${ }^{3}$ Representatives of individual voters fill the other two seats. These are Sämoan citizens who have decided not to exercise any rights to Sämoan customary land and matai titles, thereby opting out of the matai system and its associated privileges and rights.

After confirmation of general election results and, in accordance with Section 52 of the Constitution, the Head of State will convene Parliament to elect from their number a Speaker and Deputy Speaker of the House (Constitution, 4[1-2]). The Head of State will also appoint a Member of Parliament who commands the confidence of a majority of MPs as Prime Minister to preside over the Cabinet (Constitution, 32[2.a]). After the establishment of political parties, this provision of the Constitution in reality means that the leader of the political party with the majority of seats in Parliament becomes the Prime Minister after their official election by Parliament to that position.

\section{The political path to the establishment of the first political party}

Consensus politics dominated the first eight years of parliamentary proceedings. ${ }^{4}$ Sämoa’s first Prime Minister, Matä’afa Fiamë Faumuinä Mulinu’ü II, was elected unopposed in 1961 (before Sämoa gained its independence), and again in 1964 and 1967. Parliamentary politics reflected the conservative nature of traditional politics. The Matä' afa title that the first Prime Minister held was one of the four highest-ranking titles in the country. ${ }^{5}$ To have one of the Tama-a-aiga (or Royal Sons) hold the office of Prime Minister was in line with the feeling of the general public of the time. Although parliamentary debates became increasingly critical and potentially divisive in those early years, the general inclination was not to rock the boat too much. In other words, even though there were opportune moments to move motions of no confidence against the Prime Minister and his Cabinet, this did not occur during Matä'afa's first eight years as Prime Minister. ${ }^{6}$ The one attempt to move against Matä'afa and his government was later withdrawn after the PM made it clear he would resign if the proposed Forest Bill was passed. If passed that bill would have prevented the Government going ahead with its plans for the establishment of a timber industry on Savaii Island.

To contain criticism of his leadership and of government policies, Matä'afa made a practice of appointing MPs who had been critical in previous Parliaments to his Cabinet. This strategy contributed to the general nature of consensus politics in the early years of Parliament after independence. But, from 1970 onwards, Matä'afa’s faced increasing difficulties in his attempts to keep things under control.

The general election of 1970 and its immediate aftermath will go down as an important moment in Sämoa's political history. Before then, there had been only one 
tama-a-aiga in Parliament. That was Matä'afa, who had been Prime Minister since 1961. In 1970, another tama-a-aiga was elected. He was Tupua Tamasese Lealofi IV (hereafter Tamasese), who was younger than Matä'afa and was a medical doctor by profession. Tamasese was immediately identified by the newly elected MPs as an alternative to Matä'afa's conservative approach to politics. Thus, Tamasese became the representative of a new political force in Parliament, comprising members who wanted changes in leadership and government policies but who were still comfortable with a tama-a-aiga retaining the leadership.

In the contest for the Prime Ministership, yet another political force emerged. It was made up of younger, modern and educated MPs who did not mind doing away with the traditional idea of having only tama-a-aiga as Prime Ministers. One of this younger generation, Leota Itu'au, has described his involvement in the 1970 Prime Ministerial election as follows:

In 1970, when I first entered Parliament, we young and new members in the like of Le Tagaloa Pita (Leota then), A'e’au Täulupo'o, Leilua Manuao, Le'aumoana Fereti, Tauti Fuatau and Tiatia Lokeni secretly met at the old Casino Hotel to back Tupuola Efi for the top post. ${ }^{7}$

Leota Itu'au was one of the Sämoan students who had been sent to New Zealand for a university education. Leota Pita, a university graduate also entering politics for the first time, had been acting principal of the Alafua Agricultural Campus (in Sämoa) of the University of the South Pacific (USP) before he entered politics. ${ }^{8}$ The Tupuola faction therefore comprised mainly young matai, newly elected MPs and Sämoans with relatively high levels of education. Tupuola himself had undertaken law studies at Victoria University in Wellington, New Zealand, before returning to Sämoa on the death of his father and late Joint Head of State, Tupua Tamasese Mea'ole, in April 1963. ' Tupuola Efi was also a first cousin of Tamasese.

The three-way division of political orientation among the newly elected MPs was reflected in the 1970 Prime Ministerial election. As expected, Matä'afa stood again for the Prime Ministership. He won 19 votes. The newly elected and younger tama-a-aiga, Tamasese, polled 17 votes. Tupuola Efi won 10 votes. A second ballot was therefore required at which the two first cousins joined forces under the tama-a-aiga titleholder to defeat Matä'afa. The result of the second ballot was a draw. Matä'afa and Tamasese each polled 23 votes. The Speaker then adjourned Parliament until the next day and Tamasese was eventually elected by 25 votes to Matä'afa's $20{ }^{10}$ Tupua Tamasese Lealofi IV included Tupuola Efi in his Cabinet as Minster of Works.

Describing Tamasese's new-look Cabinet, Davidson noted:

It is a relatively young government, a government of well-educated men, of men who have travelled and lived abroad. Several of its members, including Tofa Fuimaono, ${ }^{11}$ have taken a leading part in the campaign to replace the restrictive matai suffrage by universal suffrage ... it looks like a government of reform - a government that will accelerate the process of both political and economic modernization ... 12 
But the Government's accelerated rate of economic and political development proved unacceptable to the majority of the public. The Tamasese Government's liberalism (if not radicalism) and its departure from consensus politics (in terms of no longer allocating portfolios on the basis of districts from which ministers came) cost it the 1973 general elections. ${ }^{13}$

The first meeting of Parliament after the 1973 elections saw Matä'afa back at the country's political helm. He polled 23 votes against Tamasese's nine and Tupuola Efi's 13. ${ }^{14}$ As a gesture of traditional respect to the other tama-a-aiga MP, Tamasese (who had regained his seat) was appointed to the cabinet.

Matä'afa passed away unexpectedly nine months before the completion of his fourth Prime Ministerial term. Given that Parliament was back to having only one tamaa-aiga among its members, it was half-expected that Tamasese would succeed the late Prime Minister. What was controversial was the manner in which the appointment was made. Instead of Parliament making its choice on the basis of majority support (Constitution, 32[2.a]), the Head of State invited Tamasese to see through Matä'afa's term. ${ }^{15}$ MPs who had rallied around Tupuola Efi as their informal leader were critical. They argued that the Head of State was out of line with the provisions of the Constitution. Outside Parliament, the scenario was interpreted as the tama-a-aiga making sure they remained in the forefront of political leadership. Despite public and parliamentary criticisms, however, the Head of State's appointment was accepted, although Parliament did become extra vigilant about preventing this sort of manoeuvre in the future. ${ }^{16}$

The aftermath of the 1976 general elections saw yet more changes in the country's parliamentary scene. Matä'afa and Tamasese's supporters now rallied around Tamasese, wanting him to continue on as Prime Minister in the next Parliament. Their efforts were in vain. The leader of the new political force in Parliament, Tupuola Efi, won the Prime Ministerial office by a majority of 30 votes to Tamasese's 16 . This was the first time since independence that a non-tama-a-aiga had held the office of Prime Minister. It represented another phase in the country's transition from traditional politics to the democratic ideals espoused in the country's liberal democratic constitution. Understandably, conservative elements within and outside Parliament argued strenuously against the new development, convinced the world was suddenly being turned upside down by Tupuola Efi and his power-hungry supporters. Backed by this conservative resentment, the outgoing Prime Minister criticised the appointment. Speaking metaphorically, Tamasese referred to the camel, which, after many years of trying, had now finally succeeded in placing itself in its master's tent. ${ }^{17}$ Although Tamasese never elaborated on his analogy, both MPs and the public knew that he was referring to his first cousin, a non-tama- $a$ aiga titleholder, eventually succeeding in placing himself in the tent (the office of Prime Minister), which, to him and his supporters, was appropriate only for the master (the tama-a-aiga). ${ }^{18}$

In response, the newly elected Prime Minister, Tupuola Efi, told Parliament that he would make sure that Tamasese was given a special place befitting his status. That place was on the Council of Deputies, ${ }^{19}$ which had been created in the Constitution to accom- 
modate the three tama-a-aiga other than the one holding the office of Head of State. At the time Tupuola Efi won the Prime Ministership, the Council of Deputies was vacant. The holders of the Tuimaleali' ifano and Matä'afa tama-a-aiga titles had passed away and their titles were therefore vacant. The new Prime Minister's gesture was culturally acceptable as the outgoing Prime Minister was a tama-a-aiga titleholder. Interestingly though, the outgoing Prime Minister had resigned the same position in late 1969 in order to contest a seat in Parliament. In reality, therefore, Tamasese was being made to take a step back to a position he had held before being involved in politics. In hindsight, perhaps, Tupuola Efi was sending out the message to Tamasese and the public that tama-a-aiga should confine themselves to ceremonial positions and not be involved in the politics of the day. Interestingly, no other tama-a-aiga has held the Prime Ministership since Tupuola Efi's victory over his first cousin and tama-a-aiga titleholder: Tupuola 'Efi was Prime Minister for two consecutive terms from 1976 to 1982; Vảai Kolone from 1982 to late 1982; Tofilau Eti Alesana from 1983 to the defeat of his budget in his second term in late 1985; Vảai Kolone again from 1986 to 1988; Tofilau Eti Alesana again from 1988 until his resignation in 1998; and Tuila'epa Sailele Malielegaoi from 1998 until the present (2005).

In the time of Matä'afa's consensus politics, once he had appointed his Cabinet, the rest of Parliament effectively became the Opposition. By 1970, however, the tone of parliamentary politics had changed. Factional politics had taken over. The Prime Ministerial election of 1970 is proof of that. The three Prime Ministerial candidates represented the three parliamentary factions that had emerged. As already noted, the Tamasese and Tupuola Efi factions later joined forces against Matä'afàs faction. The same scenario was repeated in 1973 and 1976. In 1976, however, the number of visible parliamentary factions was reduced from three to two after the unexpected death of Matä'afa in May 1975. The events of 1979 were even more intense.

After the official confirmation of the general election results of 1979 , the old rivals of Tupuola Efi and their supporters among the newly elected MPs started organising themselves against the declining but still powerful force of the incumbent Prime Minister Tupuola Efi, and his followers. The intensity of parliamentary factions had stepped up to another level. After a meeting at the place of one of their supporters, the anti-Tupuola faction finally agreed on Va'ai Kolone, a seasoned politician, to be their Prime Ministerial candidate when the new Parliament convened. ${ }^{20}$ On the day of the Prime Ministerial election, Tupuola Efi snatched victory once again, only this time, his parliamentary majority had been greatly reduced from his 1976 margin of seven seats to just one. ${ }^{21}$ Ironically, it was Va'ai Kolone's younger brother and one of the 'old hands' in the Tupuola camp that represented Tupuola's majority.

The new politics of democracy were being seen to have radical and unpleasant implications for a family-oriented society such as Sämoa. Referring to his Prime Ministerial defeat, Va'ai commented in Parliament: 'the injury is inflicted by my own brother. ${ }^{22}$ To consolidate support and win more votes with an eye to the next Prime Ministerial contest in three years, the anti-Tupuola faction established themselves as the Human Rights Protection Party (HRPP) in May of the same year. 
Before turning to the establishment and growth of political parties in postindependence Sämoa, I shall first reflect on the political developments that gave rise to their establishment.

\section{Political precursors to the establishment of political parties}

As has been shown, the first Sämoan political party, HRPP, originated within Parliament. Its primary objective was to defeat Tupuola Efi, thereby winning government. ${ }^{23}$ The origin of Sämoan political parties is therefore true to von Beyme's institutional theory that associates the origin of political parties with the prior existence of Parliament. ${ }^{24}$ It is also in line with Duverger's claim that 'first there is the creation of parliamentary groups, then the appearance of electoral committees, and finally the establishment of a permanent connection between these two elements'. ${ }^{25}$ Once Sämoan parties were formed, they would try to keep winning government. As Macridis has noted, political parties, once they are established, become the instrument to gain power and to govern. ${ }^{26}$ Moreover, once in power, a political party will try to remain there.

Incentives are needed to maintain political support. People expect recognition for their efforts in drumming up support and for toeing the party line. For example, in the combined government of two factions under Tamasese's Prime Ministership, the leader of the coalition partner, Tupuola Efi, was rewarded by being appointed Minister of Public Works. ${ }^{27}$ This is an important portfolio as it determines what public work will be undertaken, when the work starts and where. Decisions made in this portfolio can win or lose elections.

After his Prime Ministerial victory in 1970 but before he announced his Cabinet, Tamasese admitted: 'There are so many people who want to be ministers. This is a difficult task. ${ }^{28}$ Commenting on the day the Cabinet was announced, on March 6, 1970, the Sämoa Times said that the reading out of the names of ministers must be like the Day of Judgment when people would be told whether to proceed to Heaven or Hell. When Tamasese eventually announced his Cabinet, he told Parliament, 'I rise with respect to say that I cannot satisfy all Hon. Members of this House. However, I have made my selection and it was ... a very hard one.'29

Arguably, Tamasese’s appointment by Matä'afa to the latter's 1973 Cabinet was for a slightly different reason, that is, in order to strengthen Matä' afa's leadership and his grip on power within Parliament and nationally. Even though Tamasese was the leader of a rival faction, he was nevertheless a tama-a-aiga like Matä'afa. In appointing his political rival to his Cabinet, Matä'afa was making public his support and respect for the only other tama-a-aiga MP. His gesture earned him approval from Tamasese's traditional families, the general public and other parliamentarians. Matä'afa was seen as a leader who had great respect for custom and tradition. His gesture was probably also an attempt to neutralise any political influence Tamasese had within Parliament, or better still, win Tamasese supporters over to the Matä afa camp.

Va'ai Kolone's brother, Lesatele Rapi, who supported Tupuola Efi in the 1979 Prime Ministerial contest, was later reappointed by Tupuola Efi to his Cabinet. Given that Rapi was one of the ministers in the previous government, it is possible that he was promised another cabinet portfolio if he stayed with the incumbent Prime Minister. It was no 
secret in the period leading up to the 1979 Prime Ministerial contest that Vaai Kolone and his supporters campaigned strongly to win Rapi over to their side, using the family argument as their main trump card. In the end, it did not work. By then, Rapi had seen the writing on the wall: were his brother at the helm, the chance of him getting a ministerial portfolio was probably nil. For, even though Sämoa has a strong family-oriented culture, assuming that Va'ai Kolone defeated Tupuola Efi in the Prime Ministerial race, to appoint his brother to Cabinet would have been seen by the public as nepotism.

As Colin Aikman, one of the architects of Sämoa's Constitution predicted, political parties emerged due to differences in opinions and policies. ${ }^{30}$ The surfacing of these differences can be explained by the theory that associates the emergence of political parties with various aspects of modernisation.

LaPalombara and Weiner note at least two circumstances under which political parties emerge. ${ }^{31}$ First, a change might already have taken place in the attitudes of subjects or citizens toward authority. That is, individuals in the society might believe that they have the right to influence the exercise of power. Tupuola Efi, the first non-tama-aaiga to hold the office of Prime Minister, told Parliament in his victory speech:

Please do not regard the result of the ballot this morning as an illustration of Sämoa turning her back ... [on] the the tama-a-aiga, neither is Sämoa losing due allegiance to the apple of her eye. In simple terms actually Sämoa is searching for remedies to her multi-problems while the dignity and sacredness of the tama-a-aiga have continued to be jealously guarded, and the position of tama-a-aiga has continued to be given precedence by the nation. 32

Tupuola is clearly distiguishing between respect for tradition and the need to find solutions to problems of modern times. It implies that those solutions could be found in the talents of others, and not necessarily only with the tama-a-aiga leadership. Moreover, it is clear from the same speech that other citizens of Sämoa besides the tama-a-aiga wanted to exert their influence on the exercise of power.

Secondly, a section of the dominant political elite or an aspiring elite might seek to gain public support so as to win or maintain power even though the public does not actively participate in political life. As has already been seen with the rise of parliamentary factions that eventually resulted in the establishment of political parties, the dominant elite, after the enactment of the Constitution and the establishment of Parliament, were the parliamentarians. They were the ones competing for power and using their parliamentary support to achieve their objectives. Eventually, political parties emerged as fully fledged organisations whose aim was to win the public's support even though the latter was not actively participating in political life. Thus, the process leading to the establishment of Sämoan political parties accords with modernisation theory.

The change in the public attitudes whereby cultural and natural boundaries were transcended can also be attributed to factors that collectively comprise modernisation, among them the appearance of new social groups as a consequence of larger socioeconomic changes; increases in the flow of information; expansion of internal markets and transportation networks; growth in technology; and, above all, increases in spatial and 
social mobility. These aspects of modernisation seem to have profound effects on the individual's perception of himself in relation to authority. Access to a certain level of communication makes it possible for people to band together in political organisations. The secularising and individualistic effects of an educational system and the homogenising effects often associated with urbanisation might also be stimulants to the creation of political organisations, as is the shift from subsistence to a cash economy, which often involves the destruction of patterns of local authority, and greater individuality and independence in the marketplace. ${ }^{33}$

\section{The establishment of the party system}

The HRPP, established in 1979, tasted political success for the first time in the 1982 general elections, when Va'ai Kolone defeated the incumbent Prime Minister, Tupuola Efi, by one vote. Tupuola's faction became the parliamentary Opposition until Va'ai Kolone lost his parliamentary seat in an election petition five months later. ${ }^{34}$ Exercising his discretion under the Constitution, the Head of State invited Tupuola Efi once more to form a government. ${ }^{35}$ But in December 1982, a by-election gave the HRPP an extra seat $^{36}$ just in time for the Budget sitting of Parliament. That one-seat majority was sufficient for the HRRP to vote out Tupuola's Budget. On December 30, Tofilau Eti Alesana (who had taken over the HRPP leadership after his election to that position by his party on October 6) was sworn in by the Head of State as the country's next Prime Minister. On January 9, 1983, Vảai Kolone was returned to Parliament when he regained his seat in a by-election. Va'ai Kolone, however, was confined to sitting out the present parliamentary term as a backbencher while Tupuola Efi and his supporters had to wait until the next elections for another chance to unseat the Government.

Two weeks before the general elections in February 1985, Tupuola Efi and his supporters formed the Christian Democratic Party (CDP) to help them get organised for the upcoming Prime Ministerial contest. ${ }^{37}$ Unfortunately for them, the HRPP's success in the poll three years' earlier was improved further when it won 31 of the 47 seats in Parliament. ${ }^{38}$ HRPP's landslide victory, however, was maintained only until the end of 1985. Up to this point, HRPP's unwritten policy had been that only after the general election results were confirmed would its caucus decide its next leader. In their leadership meeting after the general elections, four names were put forward. ${ }^{39}$ Eventually, Tofilau Eti Alesana was given the nod to continue as leader although the vote resulting in that outcome was not as straightforward as it might seem. Supporters of Va'ai Kolone, Tofilau's main rival in this leadership meeting, were not happy with what they saw as manipulation in favour of Tofilau and his supporters. The events that unfolded after the leadership meeting were testimony to those feelings.

Before the first meeting of Parliament to decide the next government, rumours circulated that Va'ai Kolone and his supporters were breaking away from the HRPP. ${ }^{40}$ Another prominent HRPP MP, Le Tagaloa Leota Pita, and his wife, Ai'ono Fanaafi Le Tagaloa Pita, who had won her constituency's seat for the first time, had already left the party. ${ }^{41}$ Nevertheless, Tofilau was elected unopposed to continue as Prime Minister for another term. ${ }^{42}$ Rumours that the HRPP situation was unstable continued to make 
media headlines. ${ }^{43}$ These were reinforced when Tofilau's Budget, tabled in December 1985, was defeated because 11 former HRPP MPs crossed the floor to join forces with Tupuola Efi's CDP. Tofilau Eti Alesana resigned the Prime Ministership on December 27, 1985. ${ }^{44}$ The combined political forces of Va'ai Kolone and Tupuola Efi, with the former as leader and Prime Minister, became known as the Coalition Government until the next general elections in 1988. They defeated the HRPP Government by 27 votes to 19.

In the period leading up to Parliament's April 6 meeting to elect a new government, the Coalition had a one-seat majority. On the night of April 4, however, Tanuvasa Livigisitone left the Coalition camp, having been there just six weeks, and joined the rival camp of the HRPP. His nomination of Tofilau as the HRPP's Prime Ministerial candidate was seconded by Sagapolutele Sipaia. ${ }^{45}$ Having won the Prime Ministership, Tofilau appointed Tanuvasa to his new Cabinet as the Minister of Economic Affairs and Development, Tourism and Trade. Sagapolutele was appointed Chairman of the Pulenu'u (village mayors) Committee. In a speech to officially accept Tanuvasa into the HRPP camp, Tofilau made it clear to the HRPP caucus that Tanuvasa was a distant relative of his. Although Tanuvasa has stood as a parliamentary candidate for Tupua's old constituency of A'ana Alofa No. 2 against the HRPP-supported candidate, he had been a known HRPP-supporter. He had twice stood against Tupua (then Tupuola), in the 1979 and 1985 general elections. ${ }^{46}$ The mood among the Coalition when Tanuvasa 'sneaked away' to the HRPP camp was conveyed by the spokesman of the Sämoa National Party (SNP), whose political party later sided with the Coalition:

Another newcomer to politics, Tanuvasa Livigisitone hiked to Leufisa [Tofilau's residence where the HRPP MPs camped], thus betraying the trust Tupuola [or Tupua] had in supporting him during the general elections ahead of leading orator Alipia Siaosi of Leulumoega. Or was it a double job? Tanuvasa's political career is an interesting topic for discussion by political critics and students alike in years to come. Especially when this betrayal took place in a so-called Christian country 'Founded on God', and where its elders past and present, often referred to betrayal as — ia soloa i le vailalo ma ia soloa i le aufuefue [Author's note: a traditional curse which figuratively means, 'Let the betrayer be doomed underneath the ground indefinitely so that he should never be seen or heard of again']. ${ }^{47}$

To the HRPP, however, the turn of events regarding Tanuvasa's sudden defection to the HRPP camp seemed only fair, given that their 1985 victory had been snatched from them when the forces of Va'ai Kolone and Tupuola Efi had combined to defeat their budget.

On April 8, 1988, two days after their Prime Ministerial defeat, the Coalition renamed itself the Sämoan National Development Party (SNDP). ${ }^{48}$ By this time, the SNP, formed by three of the successful candidates in the 1988 general elections, had joined the Coalition because, the SNP leader, Leota Itü'au Ale, said the HRPP had not approached them for support. ${ }^{49}$

Five new political parties were established in 1993, the year in which the constitutional amendment to increase the parliamentary term was enforced. On June 4, 1993, 
the Western Sämoa Labour Party (WSLP) was founded by To'alepai Toesulusulu Si'ueva, who had been an MP from the Ä'ana Alofi No. 3 constituency for two consecutive terms (1982-84, 1985-87). He was one of the 12 HRPP MPs who, in late 1985, defected to form the Coalition Government, in which he was appointed Minister of Health. He lost his seat in 1988. Had the WSLP won a seat, it aspired to become a more effective parliamentary opposition than the SNDP, which had been rather 'mute', resulting, the WSLP claimed, in the HRPP Government becoming dangerously powerful. Among the issues the WSLP stood for were the rejection of the HRPP Government's policies on a number of development programs, and opposition to the manner in which the HRPP Government amended the Constitution in 1991 by a two-third majority of Parliament rather than through a referendum.

Another political party, the Temokalasi Sämoa Fa'amatai (TSFPP — the Sämoan Democracy of Matai), lodged its application for registration with the Justice Department on January 26, 1993. According to the leader of the TSFPP, Le Tagaloa Pita, the party had passed four main resolutions: that only the matai should have the vote; that only the matai who respected and had unwavering faith in the merits of the matai system should join the party; that the Value Added Goods and Services Tax (VAGST) was excessively burdensome on the substantial majority of the population; that the introduction of universal suffrage had duped the children of matai who had been granted the right to vote once they reached 21 years of age but not the right to stand for Parliament, as was the case with individual voters. In June 1993, the TSFPP organised a march on Parliament to present a petition registering its objections to the extension of the parliamentary term from three to five years and to the introduction of the 10 per cent VAGST.

Yet another political party, the Sämoa Liberal Party (SLP), was formed in late June $1993^{50}$ by three HRPP MPs who had been expelled from the party after they voted with the chairman and vice-chairman of the Public Accounts Committee and the Opposition to cut \$WST106,522 from the Foreign Affairs budget for the financial year 1993-94. The Prime Minister told parliament, 'If the cuts are passed by the House then I will tender my resignation to the Head of State.' The Government survived the motion by 26 votes to 19 . One of the three expelled HRPP MPs was Nonumalo Leulumoega Sofara. ${ }^{51}$ He became the leader of the SLP.

Leota Itü'au Ale, deputy leader of the SNDP since September 1992, announced in Parliament on June 26, 1995, that he was leaving the SNDP to form his own political party, to be called the Sämoa Conservative Progressive Party (SCPP). ${ }^{52}$ In the same announcement, Leota said that his party supported the incumbent HRPP Government. Subsequently, as the first MP to speak on the Budget, Leota told the House that it was a 'responsible budget' and moved that it be passed. He also thanked the Prime Minister for all he had done for the country. Leota told the Savali newspaper that in February 1995 a member of the SNDP had suggested it might be time for the current leader of the SNDP, Tupua Tamasese Efi (formerly Tupuola Efi), to step down from the leadership. Tupua had refused to give up the party leadership, hence Leota's decision to form his own party.

Another political party, the Sämoa All People Party (SAPP), was formed on March $24,1996 .{ }^{53}$ It was a landmark in Sämoa's democratic development because the party's 
leader and co-founder, Matatumua Maimoaga, became the first female party leader. Matatumua had been an HRPP MP who had tendered her resignation the day before the SAPP was created. She told people at the party launch: 'We are a legal entity, duly constituted and registered as an incorporated society with the Department of Justice ... [The party] is founded on principles and truth. It is not concentrated around individual politicians or personalities. It is truly a Party of the People. ${ }^{54}$ Matatumua on a different occasion said:

Our party has had to reject candidates that want to be members of SAPP but run as independent candidates. It is not right. It is an attempt to deceive voters, we will not tolerate deception. People must be made aware of this so that they can make an informed decision when they vote. ${ }^{55}$

Although the party does not depart from the tradition of having only matai as parliamentary candidates, it allows people as young as 16 , regardless of sex and whether or not they are matai, to be officers of its organisational structure, which includes village branches. ${ }^{56}$

Even though more political parties were formed in the period between the 1991 and the 1996 general elections, most have not been able to survive. The most important reason for this is that once the leaders lost their parliamentary seats or were unable to win a seat, that was also the end of the party. It thus left the HRPP and the SNDP as the main political parties to contest the next general election in 2001. As in 1982, 1985, 1988, 1991 and 1996, the HRPP became the Government after the 2001 general election.

The establishment of political parties saw another important development in Sämoa's political scene: the emergence of independent candidates without any party affiliation contesting general elections. Three independents won seats in the 1988 general election, ${ }^{57}$ five in $1991,{ }^{58} 13$ in $1996^{59}$ and 12 in $2001 .{ }^{60}$ The usual pattern for most, if not all, of these independents was to join one of the established political parties either immediately before the first meeting of Parliament or during the parliamentary term. After the Prime Ministerial election in 2001, however, the independents formed themselves into the Sämoa United Independents Political Party (SUIPP). Recently, though yet to be declared official by the Speaker of the House under the relevant Standing Orders, SUIPP has combined with the SNDP to form the Sämoa Democratic United Party (SDUP).

The issues of party-switching and independents later joining established parties prompted the Commission of Inquiry into Sämoa's Electoral System to make the following recommendations in its October 2001 report: (a) a candidate must remain affiliated to his party; (b) if he defects to another party, then a by-election should be called; (c) if he runs as an individual, or if he leaves the party to become an independent member, he cannot join another party in coalition, nor should he be allowed to hold a ministerial post in the ruling party for the duration of his parliamentary term; and (d) political parties must comply with the law and should be formed by election time, if they are to be accorded legal recognition. ${ }^{61}$ The Parliamentary 
Electoral Review on the Commission of Inquiry's Report 2001 accepted recommendation (a) subject to the following:

[i] A Member of Parliament elected under a Political Party which is not recognized as a Party in Parliament pursuant to Standing Orders of Parliament may become a member of a Parliamentary Party on the Leader of that Party notifying the Speaker before the member takes the Oath of Allegiance; and

[ii] A Member of Parliament ceasing to be a member of a Parliamentary Party through expulsion from that Party shall have his name omitted from that Parliamentary Party list and thereafter to become an Independent member. ${ }^{62}$

The Parliamentary Committee report also states that:

A Member of Parliament who was elected as an Independent member may join a Parliamentary Party if the leader of that Parliamentary Party gives notice of his membership required under Standing Orders before that member takes the Oath of Allegiance. $^{63}$

The Parliamentary Electoral Committee goes on to argue that the provisions already quoted provide the opportunity:

1. To a Member of Parliament who was elected under a political party which can not form a parliamentary party in pursuance to Standing Orders of Parliament to join a recognized parliamentary party.

2. [To] A member elected as an independent member to join a parliamentary party of his choice by giving notice pursuant to the Standing Orders of Parliament before he takes the Oath of Allegiance.

3. [To] A Member ceasing to be a member of a parliamentary party through expulsion to become an independent member. ${ }^{64}$

Section 15F of the Electoral Amendment Act 2005 has incorporated the recommendations of the Parliamentary Electoral Committee as follows. A candidate elected as a member of a recognised political party 'shall sit in the Legislative Assembly as a member of that political party during the term for which the Candidate was so elected'. On the other hand, a candidate who is elected as an independent or under a party that does not have the number of members for it to be recognised in Parliament as a party can join another party as long as this is done in the period between the general elections and taking the oath of allegiance in Parliament, and as long as the Speaker of Parliament is notified about this by the leader of the candidate's new party. Failure to abide by these provisions would result in the loss of the parliamentary seat, resulting ultimately in a by-election to elect a new MP for that seat. The bottom line of section $15 \mathrm{~F}$ is to prevent partyswitching during the parliamentary term.

Even though the party system has governed the political affairs of the country since 1982, political parties as such were legally recognised only after the enactment of the 
Electoral Amendment Act 1997. This amendment specifies the criteria for the registration of a political party, including that the party must have at least 100 financial members who are eligible to enrol as electors. The act also stipulates that: 'No application for registration [of a party] will be accepted after the day on which the writs for an election or by-election are issued.'

The growing importance of political parties prompted their inclusion in the Standing Orders of Parliament when the first major revision of that document since 1972 was carried out in 1997. As well as providing for the recognition of political parties in general and the Leader of the Opposition's party, the 1997 Standing Orders also stipulate that there have to be at least eight MPs in a political party before it can be recognised by the Speaker of Parliament.

The Parliamentary Electoral Review Committee (chaired by the Speaker of the House and including the Deputy Speaker as Deputy Chairperson, the Leader of the Opposition, the Leader of Government and five other MPs) sat on August 9, 2004, to discuss and refine issues relating to political parties. Recommendations of the committee have since been enacted in the Electoral Amendment Act 2005 already referred to. Previously, issues that arose relating to political parties were dealt with by a ruling of the Speaker. One such ruling is that once an MP leaves his political party, he will remain an independent for the rest of the parliamentary term. He cannot join another political party. ${ }^{65}$ Moreover, the recent announcement by the leaders of the SNDP, Mamea Ropati, and the Sämoa United Independents Political Party (SUIPP), Asiata Säle'imoa Vảai, that they had formed a combined political party called the SDUP seemed to be invalid because they had not satisfied provision 7(1-4) of the Standing Orders of Parliament, which stipulated that:

(2) A party must inform the Speaker of:

(a) The name by which it wishes to be known in parliamentary proceedings;

(b) The identity of its leader and deputy leaders;

(c) Its parliamentary membership.

The Speaker must be informed of any change [to] these matters. ${ }^{66}$

(3) A coalition between two or more parties must be notified to the Speaker but each party to the coalition remains a separate party for the purposes of the Standing Orders.

(4) In the period between the general election and the House electing a Speaker, the matters specified in this Standing Order may be notified to the Clerk.

According to the Clerk of Parliament, the announcement concerning the establishment of the SDUP is out of line because the Speaker of Parliament has not been informed of these developments as stipulated in the quoted provision of the Standing Orders. According to the Clerk of Parliament, as far as the Speaker of Parliament and Parliament are concerned, no new political party has been formed. Information given to the author on April 11, 2005, by the Ministry of Commerce, Industry and Labour at which political 
parties are officially registered confirmed that the SUIPP and SDUP have not been registered. Eventually, the Speaker informed Parliament on April 6, 2005, that the SDUP could not be recognised as a political party. Instead, what existed were the SNDP and independents, in accordance with the provisions of the Standing Orders of Parliament and the Electoral Amendment Act 2005 already cited.

\section{Effects of the party system}

The year 1991 will go down as a watershed in Sämoa's political history. For the first time, Sämoan citizens without matai titles could exercise their democratic right to elect Members of Parliament to represent the country's 41 territorial constituencies. ${ }^{67}$

The introduction of universal suffrage in the 1991 general election would not have been possible without the party system that became the main vehicle for rallying and consolidating support for the change in voting rights. More specifically, the HRPP wisely used its influence to push for the introduction of universal suffrage, arguing that there had been a proliferation of matai titles in order to give parliamentary candidates an improved chance of winning parliamentary seats. Giving all adults over 21 years of age the right to vote in parliamentary elections would help minimise the political need to confer titles indiscriminately, thereby upholding the dignity of the matai system. The introduction of universal suffrage would also give educated Sämoans who might never have the chance to hold matai titles the right to influence political decisions, thereby making use of their education to influence national developments.

Opinion in the HRPP Cabinet and caucus was divided on the question of whether or not universal suffrage should be introduced. In the end, Sämoan respect drowned these dissenting views in favour of the Prime Minister, their party leader and father of the country, as the local population prefer to call him, whose political conviction was that the introduction of universal suffrage would uphold the dignity of the matai system even if it had no other value. The political appeal of giving mothers and old women (the substantial majority of whom did not have matai titles and were therefore not able to vote in parliamentary elections) the right to vote in elections for the first time became a political magnet that drew in support behind the HRPP's cause. Even culturally conservative supporters of the HRPP who preferred that voting rights remain restricted to matai titleholders did not want to jeopardise their political support of that party by voting against universal suffrage in the referendum. Once the public gave its positive verdict on universal suffrage, the HRPP was also guaranteed another term in office. The 1991 general elections easily returned the HRPP with Tofilau Eti Alesana continuing as Prime Minister.

Looking back to Matä’afa’s Prime Ministership, which has been criticised for being so cautious that it did not achieve a great deal, it can be seen that Matä'afa and his Cabinet were constantly frustrated by a lack of political support for their development policies from a party bloc in Parliament. As already mentioned, in those days, all MPs who were not appointed to the Cabinet in effect became the Opposition, making it extremely difficult for the Government to get things through the House even if, out of respect for the Prime Minister's status as a tama-a-aiga, Parliament never went so far as to 
move a motion of no confidence against Matä'afa. As one of the members in the Working Committee of the Constitution in 1960 said: '[tama-a-aiga should] be paid the respect due to them as Tama-a-aiga and would thus ... be appointed to some office such as PM and would undoubtedly hold these positions for life. ${ }^{68}$

With the operation of the party system since the 1980s, the pace of development picked up significantly as can be seen in the discussion about whether to establish a national university; this had become a hotly debated parliamentary issue by the early 1980s. As the HRPP was committed to that cause, the strongly critical but minority voice of Tupuola Efi's opposition faction was drowned out, and the National University of Sämoa (NUS) was duly established by an act of Parliament in 1984 with a budget of only \$WST5. Today (2005), NUS has 1,700 students, about 80 academic staff and a budget of more than \$WST5 million.

Besides the NUS project, other initiatives delivered thanks to the operation of a party system include: the electrification program, which took electricity to all homes in the country; the road improvement program, which for the first time saw all roads around the country sealed; the introduction of television in the early 1990s; the establishment of a Ministry of Women's Affairs and a national Mothers of Sämoa Day in the period leading up to the introduction of universal suffrage in 1991; and the introduction of the Old Age Pension Scheme.

The parliamentary majority of the HRPP not only gave it the mandate to formulate policies but to implement them. The HRPP could also pass laws, including amendments to the Constitution, to suit its own political agenda. Until the enactment of the Special Posts Act 1989, ${ }^{69}$ Cabinet found it a constant headache that some heads of departments (HoDs), all of whom were appointed by the Public Service Commission, would not heed their instructions in terms of implementing government policies. The passing of the Special Posts Act 1989 gave Cabinet the right to hire and fire HoDs by means of a twoyear contract system. The attitudes of senior government officials quickly changed in the Government's favour.

The establishment of the party system is one thing. Keeping supporters in the party organisation is quite another and examples of party-switching are commonplace. The 11 HRPP MPs who crossed the floor in late 1985 to form a coalition with Tupuola Efi's supporters did so when it became clear that they had not been considered by Tofilau Eti Alesana for Cabinet portfolios. In 1988, another MP left the party on whose ticket he had contested the election to join another that rewarded him with a Cabinet portfolio. Va'ai Kolone's brother, whom Va'ai Kolone expected to join his faction in the Prime Ministerial election of 1979 , opted instead to remain with his old political clique. He was appointed by Tupuola Efi to his new Cabinet. The SNDP candidate who switched allegiance in 1991 when it became clear that the SNDP did not have the numbers to form a government was elected Speaker of Parliament by the HRPP, his new party.

To minimise such party-switching, new ways to reward political support had to be created, hence the passing of the Parliamentary Under-Secretary Act 1988 (although there were other arguments put forward by the Government in its support) and the successful amendment of the Constitution in 1991 to increase from eight to 12 the number of 
ministers in Cabinet. Besides creating opportunities for loyal party members, the strategy of offering political rewards also strengthened the HRPP's overall position in Parliament. Another constitutional amendment passed in the same parliamentary session in 1991 increased the number of parliamentary seats from 47 to 49. With the Prime Minister and his 12 cabinet ministers each entitled to one parliamentary undersecretary, the HRPP now had guaranteed support in Parliament from 26 of the 49 seats, giving it the numbers to continue its hold on government at least until the next general elections.

The conservative politics of the 1960s and 1970s were a great contrast with the vibrant and effective manner in which the HRPP had passed laws and introduced policy changes since the 1980s. Interestingly, the HRPP's increased power and its unbroken success in the polls has been accompanied by a sense of political paralysis not only within Parliament but within the HRPP. Le Tagaloa Pita, one of the founding members of the HRPP, told the media that the main reason he left the HRPP in late 1985 and joined forces with the CDP was because his HRPP Cabinet would not heed any advice from caucus. ${ }^{70}$ Le Tagaloa was making the point that non-Cabinet members of the HRPP caucus and the rest of Parliament felt that they were merely rubber-stamping decisions already made by Cabinet. Parliament was no longer doing its role of debating issues brought before it and making decisions accordingly. There was (and still is) a growing belief that Cabinet was no longer responsible to Parliament. If anything, it seemed to be the other way around. Thus, while the party system has achieved the intention of the framers of the Constitution for a strong Cabinet government to develop in Sämoa, it is coming to be disliked by the majority of parliamentarians, except, of course, those in Cabinet.

It took a controversial government policy for these anti-HRPP and anti-party system political sentiments to surface. In the early 1990s, the HRPP Government introduced the VAGST. Given the secure HRPP majority in Parliament at the time, the Opposition SNDP felt powerless to use Parliament to prevent the Government from implementing its VAGST policy. But with the public rallying behind the SNDP to get the Government to reverse its decision, the anti-HRPP forces wisely turned to other, traditional power bases in their fight against the Government. Thus, the Tumua ma Pule ma "Äiga (TPA) protest movement was born. The inclusion of traditional institutions in the movement introduced an added dimension and intensified the magnitude of the protest. The general talk around the country and within the traditional political elite was that Parliament had no legitimacy in the country as it was a foreign and relatively new institution. Symbolically undermining the Prime Minister and his Cabinet, the protestors bypassed them and handed their petition instead to the Head of State because of his traditional status as one of the four tama-a-aiga titleholders. The Head of State's response was a delaying tactic that eventually resulted in the petition being handed back to the Government to consider. Although the VAGST on some goods was reduced and on others eliminated, the general policy remains unaffected.

There was also a general public feeling that the party system could easily act in the interest of no one but the party in government. That sentiment had some justification. One of the controversial issues in the TPA's petition related to the report of the Controller and Chief Auditor (CCA) in which he pointed to corruption in high places. 
After several heated debates in Parliament and repeated court actions involving law suits against the Government by the CCA, the issue was put to rest through constitutional means. Taking advantage of its two-thirds majority in Parliament, the HRPP easily passed a constitutional amendment in which the CCA's term of office was reduced to a three-year contract in line with the rest of the heads of departments under the Special Posts Act 1989. The CCA, who had been suspended from his job by that time, was given the right to reapply. He did not.

Another complaint in the TPA petition related to the extension of the parliamentary term from three to five years. What was controversial about this extension was that rather than introducing that amendment in the next Parliament, as the majority of the voting public had expected, the HRPP enforced the extension in the current Parliament.

Thus, although the establishment of the party system brought about positive policy changes that benefited the majority of the public, it also introduced elements that made the public sceptical of not only the party system but democracy generally. The passing of a number of laws (such as those discussed above; namely, the increase in Cabinet positions, the Parliamentary Under-Secretary Act 1988, the Special Posts Act 1989, the reduction of the CCA's contract period and the extension of the parliamentary term) that seemed engineered by the HRPP for its own benefit contributed to that scepticism. Negative aspects of the HRPP regime aside, its ability to consolidate and win support can be attributed to its organisation and campaign strategies. I shall discuss its organisation first.

\section{Party organisation}

Because of its long record of success at the polls, the HRPP seems to be the most organised of all the existing political parties. Therefore, I shall discuss that party here as an example of a Sämoan political party structure. The party was founded in May 1979. It's name, Human Rights Protection Party reflects the international ideologies of the time; however, when asked how the name was derived, one senior HRPP MP said that it was a catchphrase in Sämoa arising out of the Tupuola Government's undermining of people's rights. ${ }^{71}$ Moreover, the late Prime Minister, Tofilau Eti Alesana, said that the establishment of the HRPP was directly related to the Tupuola Government's 'infringement of the right of the people, especially the rights of the public servants' ${ }^{72}$ The immediate aim of the party was to overthrow the Tupuola Government. ${ }^{73}$ Its long-term aim, according to one former prominent HRPP MP, was to prevent Tupuola from ever again becoming the Prime Minister of Sämoa. ${ }^{74}$

The official objectives of the party are very general:

1. To foster political education and provide leadership necessary to safeguard the rights, liberties, privileges and freedoms of the Sämoan people and individuals; to protect their interests and to secure ... [for] them peace, security and prosperity in their native land; and to provide institutions which promote and guarantee ... [for] them economic, social and political welfare.

2. To uphold the constitution of Western Sämoa. 
3. To encourage and foster amongst the Sämoans collectively and individually the spirit of independence, self-reliance, industry, assertiveness and acquisitiveness.

4. To demand and guarantee the protection of the vital Sämoan interests by means of appropriate constitutional safeguards in the constitution of Western Sämoa or any future constitution of any government to be established in Western Sämoa.

5. To devise the means of informing the ... [Sämoan] people by means of political education or otherwise about the international or local body politics, and finer and worthy aspects of other cultures, arts, music, philosophy, economics and other disciplines.

6. To promote and encourage the means of improving the living standards of the people of Sämoa.

7. To do all such other lawful things as are incidental or conducive to the attainment of the foregoing ... [objectives].

Women also had an influence on shaping the party. The wife of one former MP said that having always accompanied her husband to the HRPP's caucus meetings at Vaivase, she became tired of waiting outside for her husband. She and the wives of the other MPs therefore decided to organise the women's section of the party. At the time, she was reading the book by PNG's Chief Minister, Michael Somare, Sana: An Autobiography of Michael Somare, on how he had organised the Pangu Party. Somare's book gave her and the other women ideas on how to strengthen the organisation of the HRPP. Not only did the women conduct numerous fundraising activities for the party, they helped win over to the party the support of elected MPs and intending candidates through their spouses. ${ }^{75}$

The HRPP's constitution established the party's organisational structures and their respective functions. Elected every year at the party's annual general meeting (AGM), the executive committee comprises the president (the leader of the parliamentary caucus), vicepresident (caucus member), secretary (not a caucus member), treasurer (caucus member), six members appointed by caucus, one non-caucus member each from Upolu and Savaii Islands and one representative of women (HRPP Constitution, Art.7.a[i-vii]). All party policies are formulated by the executive committee but have to be approved at the AGM. They are made available to constituencies before by-elections and general elections (Art. 3). The constitution also provides for the establishment of committees such as those for fundraising, policy and planning, campaigning and education, women, youths and membership. The president and leader of the party can be present in meetings of all the committees (Art. 6). Membership of the party is open to all people aged 18 years and over, who have paid an initial \$WST2 registration fee and \$WST5 every year thereafter (Art. 4).

For a long time, Sämoan parties relied solely on their own members and donations for funding. Generally, all parties were reluctant to publicise the names of their donors as this was one of the conditions under which financial and other means of support were given to them. Recently, the Government budget has allocated a total of \$WST100,000 for the support of party offices. That amount is divided between the parties on the basis 
of the number of parliamentary members each has. Given that in the present Parliament about two-thirds of its members are HRPP MPs, the bulk of present government funding for political parties goes to the Government party, the HRPP.

\section{Party campaign strategies}

Party campaigns can be divided into two general categories: the collective party campaign and the individual candidate's personal campaign. For an example of an individual's personal campaign, see So'o 1998 a. ${ }^{76}$ Examples of party campaign strategies, however, are given here.

In the 1982 general elections, the names and photographs of HRPP candidates were published in a party statement, thereby making it the first post-independence political party to utilise modern campaign tactics. For the first time, parliamentary candidates were made known to the public. The HRPP declared that its aim was to change the Government. ${ }^{77}$ In 1985, the HRPP adopted the practice of including not only the photographs of its candidates in the party's official campaign statement, but the programs and projects the party intended to complete in the next term. For example, its 1991 election manifesto stated its policies on roads, water, the country's electrification program, wharves, communication, town beautification, agriculture, education, hospitals, environment, sports development, tourism and other revenue-earning industries, women, old-age pensions and reconstruction of houses damaged by Cyclone Ofa. Because copies of this document were distributed throughout most parts of the country by the HRPP candidates and their supporters, a substantial majority of the public had a good idea of who the candidates were and what the party intended to do.

Although the CDP and SNDP, in 1985 and 1988 respectively, adopted the practice of publicising the names of their parliamentary candidates and their programs, neither party included the photographs of its members in their party statements. The reasons for this are not clear. Perhaps, these parties were not as well organised (in terms of having a party constitution and other necessary party regulations with which to discipline party members) and did not have enough funds for such activities. Or perhaps they suspected that the HRPP was more popular among the people, hence identifying their candidates would not help the party's cause. Whatever the reasons, the fact that a substantial majority of voters did not know who the parties' candidates were probably contributed to their lack of success at the polls. In 1991, at the launch of its manifesto, the SNDP invited all its candidates who were present to line up at the front of the hall so that members of the public could see who they were. About 400 people were present and most of them were SNDP supporters. The party campaign strategies given above have generally remained unchanged. ${ }^{78}$

\section{Conclusion}

The nature of the party system and the manner in which Sämoan political parties have developed are in part a reflection of the Sämoan context. For example, the selection of candidates for elections, the campaign strategies adopted and some of the factors that 
contributed to the emergence of the party system, contain elements of Sämoa's traditional political culture. On the other hand, the emergence of the party system also lends credence to the modernisation theory of the origin of political parties espoused by Labalombara and Weiner. Duverger's thesis that political parties originate within Parliament is also proven in the case of Sämoa.

Despite some of the politically stinging criticisms against political parties and the party system, it seems clear that these institutions of democracy are here to stay. Ironically, some of the staunchest critics of political parties and the party system have in the end reversed their original positions and formed their own parties. Their change of view follows the realisation that to have any hope of winning government, they must form political parties. The Government, on the other hand, has found it politically useful that it has been able to utilise the party system to get some of its controversial policies through Parliament. The issue of the Executive becoming so powerful that Parliament feels powerless to control it remains a problem for which the constitutional experts will have to find solutions. Meanwhile, the party system and democracy in general are becoming entrenched in Sämoa even if they are still not fully endorsed by a substantial section of the local population.

\section{Footnotes}

1 The Constitution of the Independent State of Sämoa (Constitution). 1962.

2 Parliament passed this amendment on November 28, 1991.

3 Sämoa Electoral Act. 1963. 5[1].

4 So'o, A. 1996. 'O le fuata ma lona lou: Indigenous institutions and democracy in Western Sämoa.' PhD Thesis, The Australian National University. pp.158-65.

5 The other three of these titles are Tupua Tamasese (which at the time was held by Mea'ole, who was a Joint Head of State), Mälietoa (which is still held by Tanuamfili II, who was Joint Head of State with Tupua Tamasese Mea'ole before the latter died in April 1963), and Tuimaleali'ifano (who held the post of Deputy Head of State). These four titles are called Tama-a-aiga, literally, 'Sons of the Families'. Tama-a-aiga has been translated as 'Royal Sons' because they are the sons of Sämoa's royal lineages that have survived to modern times.

6 So'o, op. cit. p. 163.

7 Ale, L. L. I. 1990. 'The development of political parties in Western Sämoa.' An unpublished essay in the author's possession. p. 6.

8 Sämoa Times, February 13, 1970.

9 Pacific Islands Monthly, April 1970. p. 50; Davidson, J. W. 1967. Sämoa mo Sämoa: The Emergence of the Independent State of Western Sämoa. Melbourne: Oxford University Press. p. 428.

10 Sämoa Hansard. 1970. Vol. I. p. 7.

11 This was the same Fuimaono who had moved a motion of no confidence against Matä afa in the previous Parliament.

12 Pacific Islands Monthly, April 1970. p. 51.

13 So’o, op. cit. pp. 1972-3.

14 Sämoa Hansard. 1973. Vol. I. pp. 5-6.

15 Sämoa Hansard. 1975. Vol. I. p. 11.

16 So'o, op. cit. pp. 180-1.

17 Sämoa Hansard, 1976, Vol. I. p.14.

18 So'o, op. cit. pp. 185-6. 
19 Sämoa Hansard. 1976. Vol. I. p. 14.

20 Sämoa Times, February 16, 1979.

21 Sämoa Hansard. 1979. Vol. I. p. 7.

22 Ibid,.p. 10.

23 Pacific Islands Monthly, April 1980; Savali, November 13, 1979.

24 von Beyme, Klaus. 1985. Political Parties in Western Democracies. New York: St Martin's Press. p. 15.

25 Duverger, M. 1954. Political Parties: Their Organization and Activity in the Modern State. Cambridge: University Printing House. p. xxiv.

26 Macridis, R. C. 1967. 'Introduction: The history, functions, and typology of parties.' In R. C. Macridis (ed.), Political Parties: Contemporary Trends and Ideas. New York, Evanston, London: Harper \& Row Publishers. p. 9.

27 Ale, op. cit. p. 4.

28 Sämoa Times, February 27, 1970.

29 Sämoa Hansard. 1970. Vol. I. p. 14.

30 Minutes of the Working Committee on the Constitution. February 3. 1959.

31 LaPalombara, J. and M. Weiner. 1966. 'The origin and development of political parties.' In J. LaPalombara and M. Weiner (eds), Political Parties and Political Development, Princeton: Princeton University Press. p. 19.

32 Sämoa Hansard. 1976. Vol. I. p. 11.

33 LaPalombara and Weiner, op. cit. pp. 19-21.

34 Sämoa Times, October 11, 1982.

35 Ibid. September 24, 1982.

36 Ibid. December 3, 1982.

37 Ibid. February 8, 1985.

38 Western Sämoa Gazette, 14 [3], March 2, 1985.

39 So'o, op. cit. p. 205.

40 Sämoa Times, March 22, 1985.

41 Ibid. March 15, 1985.

42 Sämoa Hansard, 1985. Vol. I. pp. 2-3.

43 So'o, op. cit. pp. 416-17.

44 Sämoa Hansard. 1985. Vol. I. p. 363.

45 Observer, March 13, 1988; Sämoa Times, April 8, 1988.

46 Western Sämoa Gazette, 9 [3], March 9, 1979; 14 [2], February 7, 1985.

47 Ale, op. cit. p. 18.

48 Observer, April 3, 1988.

49 Ale, op. cit. p. 18; Sämoa Times, March 4, 1988; Observer, March 2, 1988.

50 Observer, March 16, 1994.

51 Ibid. March 16, 1994.

52 Savali, June 28, 1995.

53 Sämoa Newsline, March 23, 1996.

54 Ibid.

55 Quoted in Observer, April 10, 1996.

56 Sämoa Newsline, March 24, 1996.

57 Observer, March 23, 1988.

58 Ibid. April 10, 1991.

59 So'o, A. 1998. 'Sämoa political review.' The Contemporary Pacific: A Journal of Island Affairs, Vol. 10, No. 1. pp. 222-30, at p. 223.

60 So'o, A. 2002. 'Sämoa political review.' The Contemporary Pacific: A Journal of Island Affairs, Vol. 14, No. 1. pp. 224-36, at p. 224.

61 Muli'aumaseali'i, S. 2001. Report of the Commission of Inquiry on Sämoa's Electoral Act 1963 and Its Amendments. Apia: Government Printing Press.

62 'Report of the Parliamentary Electoral Review Committee.' Parliamentary Paper 2002/ 2003, No. 52 . p. 7.

63 Ibid. 
64 Ibid. pp. 7-8.

65 Author's personal communication with Mase To'ia Alama [Clerk of Parliament], August 3, 2004.

66 Standing Orders of Parliament, 1997, 19.2.

67 Members occupying the other two seats of Parliament are an exception to the rule as they represent those who have opted out of Sämoan customary rights to ownership of land and matai titles. MPs occupying those seats and those who vote them into Parliament do not hold matai titles. They are registered on the Individual Voters Roll.

68 Minutes of the Working Committee on the Constitution, March 21, 1960.

69 This act was repealed in 2003 to increase from two to three years per term of the Head of the Corporation/Ministry.

70 Sämoa Times, March 15, 1985.

71 So'o, 1996, op. cit. p. 194.

72 Quoted in Pacific Islands Monthly, September 1988. p. 46.

73 Pacific Islands Monthly, April 1980. p. 19; Savali, November 13, 1979.

74 So'o, 1996, op. cit. p. 193.

75 So'o, 1996, op. cit. p. 197.

76 So'o, A. 1998. 'The price of political campaigning in Sämoa.' In P. Larmour (ed.), Governance in the Pacific, Canberra: Asia Pacific Press. pp. 289-304.

77 Observer, February 25, 1982.

78 See also So'o, 1996, op. cit. pp. 224-52. 